\title{
A 14. századi anyagi kultúra tükröződése Magyarországi Klemencia halotti inventáriumában
}

\author{
BARTHA ANNAMÁRIA \\ Szegedi Tudományegyetem, Történelemtudományi Doktori Iskola, Medievisztika PhD program \\ H-6722 Szeged, Egyetem u. 2., bartha.ancsa84@gmail.com
}

Bartha, A.: The inventory of queen Clémence of Hungary as a source of 14th century material culture

Abstract: This article investigates the inventory of belongings owned by Clémence of Hungary, queen of France. The inventory, created after her death, lists within 748 „items" the estates of Clémence, and the exact prices for which they were sold. Among others, descriptions of various pieces of clothing, jewellery, religious and secular pieces of art, numerous horses and chariots, and even the royal tablewear are kept by this interesting source of 14th century culture history.

Keywords: medieval queenship, court life, dynastical representation

\section{Bevezetés}

Az inventárium, mint forrástípus használatakor nehézséget jelent a leírások valós tárgytípusokkal való megfeleltetése, ami nem meglepő egy olyan korszak esetén, amikor nem egyszer a legértékesebb ötvösműveket is beolvasztották tulajdonosaik, ha hirtelen pénzszúkébe kerültek. ${ }^{1}$ Ugyanakkor pont a tárgyak hiánya miatt fontos, hogy vizsgáljuk ezeket a leírásokat, mert csak ezek által kaphatunk képet az adott időszak használati eszközeiről, kedvelt tárgytípusairól és divatjáról.

Magyarországi Klemencia² királyné hagyatéki leltára a francia középkor egy olyan időszakának uralkodói reprezentációjába enged betekintést, amikor a királyné apósa, a néhai Szép Fülöp szigorú 1294. évi törvénye, mely a nemesfém ékszerek és koronák, drágakövek és díszhintók birtoklásának jogát a királyi család tagjai számára tartotta fenn ${ }^{3}$, még éreztette hatását. Az udvar szigorúan szabályozta azt is, ki mennyi és milyen minőségű ruhával rendelkezhetett. ${ }^{4} \mathrm{E}$ szabályoknak köszönhetően első pillantásra látszott, hogy ki melyik társadalmi csoporthoz tartozott.

Az inventárium segítségével betekintést nyerhetünk egy királyné ruhatárába, ékszeres ládikójába, étkezőjébe és istállójába. Láthatunk olyan tárgyakat, melyek a királynéi reprezentációt szolgálták, de olyanokat is, amelyek a királyné legszemélyesebb környezetében voltak, csak kevesek számára láthatóan.

\section{Klemencia inventáriuma}

Az inventárium Pierre Clairmbault (1651-1740) gyűjteményének részeként került a Bibliothèque Nationale de France-ba. 1890-ben a 99 oldalas eredeti iratot ${ }^{5}$ más, 1287 és 1337 között keletkezett dokumentumokkal

$1 \quad$ Kovács 1998. a. 183., Freeman 1963. 327.

2 Károly Róbert húga, Martell Károly és Habsburg Klemencia legkisebb lánya 1293-ban született. Szülei halála után nagyanyja Árpád-házi Mária nápolyi királyné nevelte. 1309-ben Károly Róbert feleségül kérte egy magyar arisztokrata számára, és ugyanakkor II. Jakab aragón király is megkérte harmadik fia, Ferdinánd számára. Azonban egyik frigy sem köttetett meg. Végül 1314 decemberében eljegyezték X. Lajos francia királlyal, akivel 1315. augusztus 19-én házasodtak össze, és 24-én megkoronázták. Házasságuk nem tartott sokáig, mert 1316. június 5-én Lajos meghalt. Klemencia terhes volt, november 13án életet adott gyermekének, akit I. Jánosként királlyá koronáztak, de mindössze öt napig élt. Ezt követően Klemencia özvegy királynéként élt Franciaországban 1328. október 13-án bekövetkezett haláláig. (Kristó 2005. 14-15., Bertényi 2000. 69., Sroka 1998. 24-25., Dümmerth 1982. 284-290., Lalou 1991. 1205-1206., Bartha 2013.) Klemencia életéről részletesebben lásd: Huffelman 1911., Brown 1988., Brown 1978., Proctor-Tiffany 2007.

3 Proctor-Tiffany 2007. 58.

4 Proctor-Tiffany 2007. 96

5 A lapok, amikre az inventáriumot írták 212 milliméter szélesek és 292 milliméter hosszúak, méretük megegyezik a modern európai papírlapok méretével. A szöveget egy oszlopba írták, balról 3, jobbról 3,9, a lap aljától 4,5, a lap tetejétől 2,5 centiméter margót hagytak. Barna tintával írták, vékony, minőségi papírra. A lapokon két eltérő, egy sisakot és egy kereket ábrázoló vízjel található, az előbbi 1321 és 1335, a másik 1315 és 1321 közé datálja a dokumentum keletkezését, ez alapján valószínúsíthető, hogy Klemencia halála körül keletkezett és nem későbbi másolat. A papírok Észak-Itáliából származnak. A szöveg egy kéz munkája, oldalanként 30-31 sort írtak. Ez alapján Mariah Proctor-Tiffany feltételezi, hogy Klemencia halála után az özvegy királyné különböző birtokain összeírt vagyontárgyak egyes leltárainak az egyesített, végső tisztázata lehet. Bár eredetileg sem az oldalak, sem az „item”-ek nem voltak számozottak, később valaki számokat írt a kézirat jobb sarkába arab számjegyekkel. (Proctor-Tiffany 2007. 24-25.) 
fúzték össze. ${ }^{6}$ 1874-ben Louis Douët-d'Arcq átírta és kiadta Inventarie et vente après décès des biens de la reine Clémence de Hongrie, veuve de Louis le Hutin, 1328 címmel Nouveau recueil de comptes de l'argenterie des rois de France címú munkájában. ${ }^{7}$

Az inventáriumot 1328. október 18-án kezdték el összeállítani Klemencia végrendeletének végrehajtói és a király küldöttei, Jean de Billouart és Pierre des Essars jelenlétében. Az ékszerek összeírása négy napot vett igénybe, a becslést a korszak hat legjelesebb ötvösmestere: Simon de Lille, Jehan Pascon, Félix d' Auccurre, Jehan de Toul, Pierres de Besançon és Jehan de Lille végezték el. ${ }^{8}$ Az inventáriumban 748 itemben sorolják fel a királyné különböző tárgyait, részletes leírással, súlyukkal, becsült értékükkel, a vásárló nevével. Egyes esetekben lejegyzik azt is, ha nem a becsült értékükön keltek el a tárgyak.

A tárgyak felbecslésére és eladására október 18 és 21 között került sor. Az értékesebb tárgyakat a király vásárolta meg képviselői útján. A többi tárgyat a végrendelet végrehajtóin és a királyi család egyes tagjain ${ }^{9}$ kívül több esetben nem nemesek és hivatásos kereskedők vásárolták meg. ${ }^{10} \mathrm{Ez}$ a tény, valamint az, hogy a befolyt összeg gyakran nagyobb, mint amennyire az árut becsülték, azt mutatja, hogy az eladás afféle árverés lehetett..11

\section{Koronák}

Az özvegy királynénak halálakor négy korona volt a tulajdonában ${ }^{12}$, ami arra enged következtetni, hogy különböző koronákat hordott az egyes udvari alkalmaknak megfelelően. A legértékesebbet, amit 800 livre-re ${ }^{13}$ becsültek, és amit 10 nagy rubin, 50 kis smaragd és 40 nagy gyöngy ékesített, végrendeletében unokaöccsére, nővére, Beatrix fiára, Umbertre hagyta. ${ }^{14}$ Ezt Simone de Lille készítette ${ }^{15}$, alakjáról a királyné sírszobrán ábrázolt korona révén alkothatunk képet, amelynek félgömbös mélyedéseit eredetileg a valódi korona ékköveivel színben harmonizáló kő- és üvegberakások tölthették ki. ${ }^{16} \mathrm{~A}$ másik három koronát a király vásárolta meg. $\mathrm{A}$ második legértékesebbet 600 livre-re becsülték; 4 nagy rubin, 4 nagy smaragd, 16 kis rubin és ugyanennyi kis smaragd, 80 gyöngy és 8 alexandriai rubin díszítette. ${ }^{77} \mathrm{~A}$ harmadik koronát két fémszálra építették, 6 rubin, 6 smaragd, 48 nagy gyöngy és 6 kis alexandriai rubin, valamint 6 kis smaragd ékesítette és 400 livre-re becsülték az értékét. ${ }^{18} \mathrm{Az}$ utolsó korona törött volt, és 160 livre-t ért. ${ }^{19}$

\section{Ékszerek}

A királyné kilenc gyűrűje közül egy smaragdgyűrủ nem talált gazdára ${ }^{20}$, hatot a király vásárolt meg ${ }^{21}$, egy kis rubinköves gyűrüt ${ }^{22}$ pedig Jeanne de Evreux, IV. Károly özvegye. Érdekes, hogy a leltárban sem fülbevalók, sem karperecek nem szerepelnek. Különböző nyakékei voltak: gyöngysorok és különböző függők, medálokat, amiket a királyné szalagra, vagy láncra füzve hordhatott a nyakában, vagy esetleg diadémként a homlokán. Kilenc függője közül egy kalcedonból' ${ }^{23}$, a többi zafírból készült. ${ }^{24}$ Ezek csak méretükben ${ }^{25}$, színükben, alakjukban ${ }^{26}$,

6 Proctor-Tiffany 2007. 24., http://gallica.bnf.fr/ark:/12148/btv1b9000674p/f9.image

7 A továbbiakban Inventárium. Ezt az átírást használtam jelen munkához, a szöveget Gál András fordította, segítségét ezúton is köszönöm. Az egyes tárgyakat item szerint hivatkozom.

8 Inventárium 37-38.

9 Különösen Jeanne de Evreux özvegy királyné. Jeanne hagyatékának és reprezentációjának Klemenciáéval való kapcsolódási pontjaihoz lásd: Holladay 2006. 83-86.

10 Például Pierre Neelle, Guillaume le Flament, Johan kereskedő, Eustace kalmárnő.

11 Huffelman 1911. 69-70.

12 Ezzel szemben Jeanne de Evreux inventáriumában 11 korona szerepelt. Proctor-Tiffany 2007. 64-65.

13 Klemencia inventáriumában az árakat párizsi fontban adták meg. 1 livre 20 sou-t és 240 denier-t ért. Proctor-Tiffany 2007.293.

14 Item 1. „un bon chappel d'or ouquel il a 10 gros balois 50 petite emeraudes et 40 grosses pelles, présié 800 I par.. Lessié au Dalphin par la testament"

15 Huffelman 1911. 68-69.

16 Proctor-Tiffany 2007. 65-66., http://www.kornbluthphoto.com/Clemence.html

17 Item 3. „un bon chappel d'or ouquel il a 4 gros balois, 4 grosses emeraudes, 16 petit balois, 16 petit emeraudes, 80 pelles et 8 rubiz d'Alixandre, présié 600 I, vendu au Roy"

18 Item 2. „une bon chappel sus deux vergetes où il a 6 balois, 6 emeraudes, 48 grosses pelles, 6 petit rubis d' Alixandre et 6 petit emeraudes, présié 400 I parisis, vendu au Roy"

19 Item 4. „un chappel dépécié, (...) présié 160 I par., vendu au Roy”

20 Item 11. „une belle emeraude en un annel, présié 20 l”

21 Item 5-10., 12.

22 Item 19. „un petit annel d'un rubiet, vendu à la royne Johanne d' Evreus”

23 Item 53.

24 Item $37-44$.

25 Például a 40. item esetében, ahol kiemelik, hogy nagy zafír, amit az ára is mutathat, hiszen 100 livre-re becsülték az értékét.

26 A 38-as itemben szereplő zafírt felhőformának nevezi, ami azt jelenti, hogy nem teljesen szabályos, tökéletlen, míg a 44-es tételt laposnak nevezi. 


\section{A 14. SZÁZADI ANYAGI KULTÚRA TÜKRÖZŐDÉSE MAGYARORSZÁGI \\ KLEMENCIA HALOTTI INVENTÁRIUMÁBAN}

és foglalatukban ${ }^{27}$ térnek el. Klemenciának négy gyöngysora volt, mindegyik több szálból állt $\left(7^{28}, 8^{29}, 9^{30}, 21^{31}\right)$, mindegyik szálon 20 gyönggyel. Ezek egytöl-egyig a királyhoz kerültek.

A királynénak a szöveg által legtöbbször fermail-ként említett ruhakapcsai és brossai a felsőruha nyakkivágásának összefogására szolgáló, a középkori társadalom minden rétegében elterjedt, férfiak és nők által egyaránt hordott ékszertípus ${ }^{32}$ luxuskivitelü példányai voltak. Közülük a legszebbet és legértékesebbet d' Alençon grófára hagyta. A négyzet alakú kapcson egy rubin, 4 smaragd és 16 gyöngy helyezkedett el, és 150 livre-re becsülték. ${ }^{33}$ Két másikat Bourbon hercegének és Beaumont úrnak szánt végrendeletében. Az előbbi egy, a közepén nagy zafírral, Franciaország címereivel, négy rubinnal és hat gyönggyel díszített ruhakapcsot kapott, amit 50- livre-re becsültek. ${ }^{34} \mathrm{Az}$ utóbbira pedig egy smaragdos kapcsot hagyott, 4 rubinnal, 4 kis rubinnal és 16 gyönggyel, 60 livre értékben. A király 14 brossot vásárolt ${ }^{35}$, ezek közül egy $M$ betüt ${ }^{36}$, egy $B$-t formázott és egyet Szent János ábrázolás díszített ${ }^{37}$, egy másik pedig A-t formázott Magyarország és Franciaország címerével. ${ }^{38}$ Az M utalhatott Szúz Máriára, vagy Klemencia nagyanyjára, Árpád-házi Máriára, esetleges korábbi tulajdonosára is. A B pedig talán a Beatrix névre, melyet többen is viseltek Klemencia családjában, például nővére is. ${ }^{39}$ Sajnos az $\mathrm{A}$ betú megfejtése nem ilyen egyértelmú. A geometrikus formákon kívül${ }^{40}$ állatábrázolásokat is találunk: két papagájt ${ }^{41}$, két szarkát ${ }^{42}$ és egy kakast. ${ }^{43}$

Az ékszerek közé sorolja a „rózsafüzéreket", ami azonban még nem felel meg a ma ismert rózsafüzérnek, mert az csak a 15. században alakult ki. Ezeket a füzéreket kézben, nyakba akasztva, vagy övre függesztve egyaránt hordták, és karikába fűzött gyöngysorokból álltak. A gyöngyök száma nem volt állandó, valószínűleg különféle alkalmakkor különféle imákat mondtak el. ${ }^{44}$ Klemencia hat ilyen füzérrel rendelkezett, melyek közül négy értékes rózsafüzér ${ }^{45}$ a király, és két csekélyebb értékü ${ }^{46}$ Jeanne de Evreux tulajdonába került. Mindegyik luxuskivitelű volt, gyöngyökből, értékes drágakövekből, arany és ezüst díszekből készült, s a szemek száma eltérő volt. Sajnos nem elég részletes a leírás ahhoz, hogy ezek használatáról és felépítésérôl pontos képet kapjunk. Például az egyik 48 nagy gyöngyből, 6 zafírból és 12 aranycseppből és egy másik gyöngyből álltt ${ }^{47}$, vagyis 67 szemből és 100 livre-ért kelt el. A legnagyobb 113 elemből állt, 101 gyöngyből és 12 aranycseppből és 40 livre-ért adták el. ${ }^{48} \mathrm{~A}$ legértékesebbet 150-livre-re becsülték, 92 gyönggyel, 5 rubinnal és 5 zafírral díszítették ${ }^{49}$, vagyis 102 szemből füzték. A többi esetben nem tudjuk, pontosan mennyi szemből készültek a füzérek, de az egyiken még valamiféle ereklye ${ }^{50}$ is helyet kapott.

\section{Klemencia ruhái}

Az öltözék jól tükrözte viselője társadalmi rangját, ezért a 14. században szigorúan szabályozták, hogy ki mennyi ruhát birtokolhatott. A hercegek, grófok és bárók, illetve feleségeik évente legfeljebb négy öltözetet vásárolhattak, míg egy polgárasszony mindössze egyet, hacsak nem volt jelentős földbirtoka. A ruhák minőségét is szabályozták, például egy 2000 livre-nél kevesebb vagyonnal rendelkező polgár csak olyan ruhát viselhetett, melynek anyaga rőfönként legfeljebb 10 sou-t ért. Az emberek többségének csak egy, színezetlen gyapjú

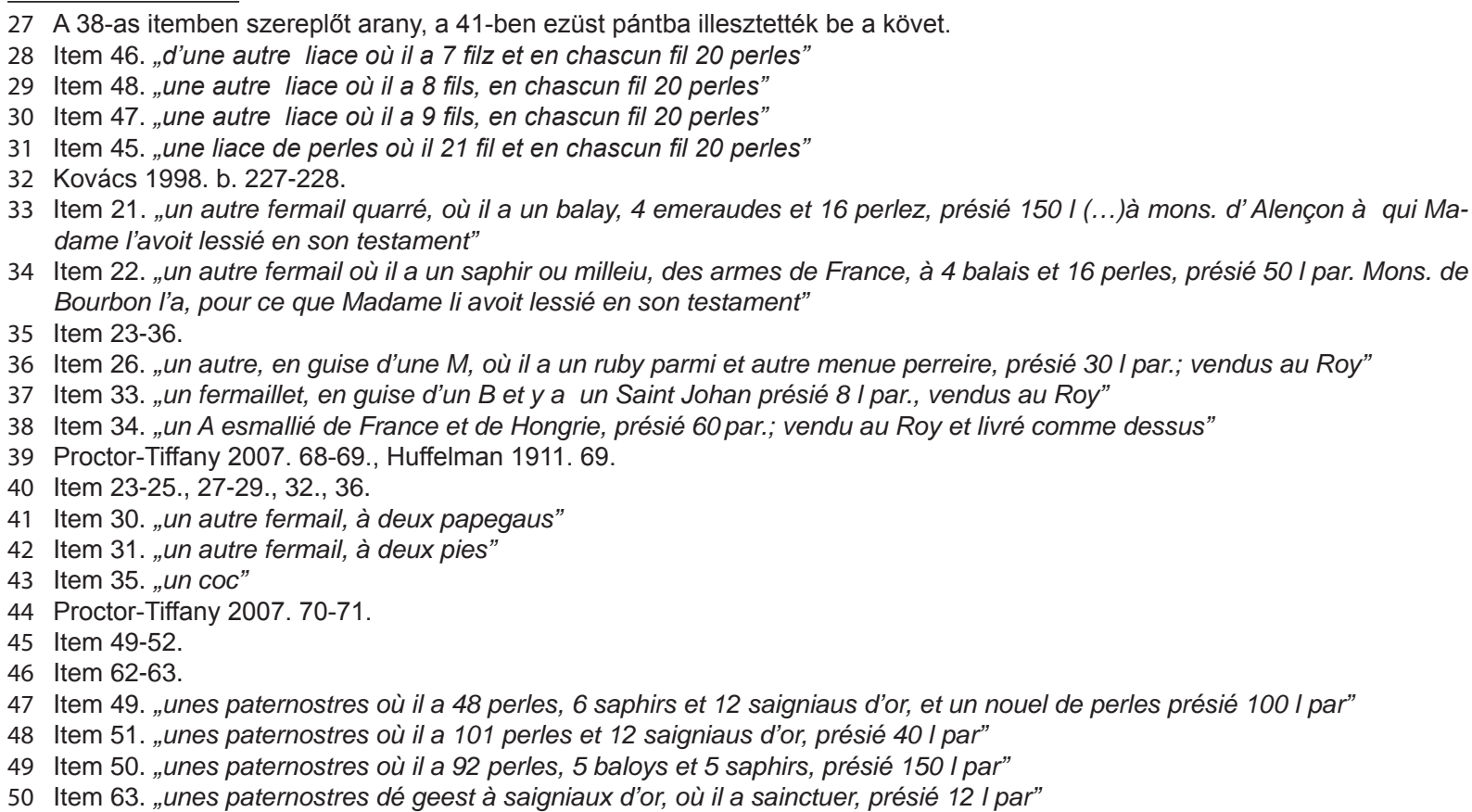


öltözéke volt. Ennek a szabályozásnak köszönhetően mindenkiről első pillantásra látszott, hogy a társadalom mely rétegéhez tartozott. ${ }^{51}$

Klemencia ruháinak anyaga, színe és a különféle ruhatípusok mind a királynői hatalmat demonstrálták. A királynénak saját szabója volt, Johan de Gaangni, aki az udvar számára készítette és javította a drága öltözeteket. Klemencia végrendeletében ő és felesége egyaránt feltűnik, mint a háznép fontos tagjai. ${ }^{52}$

Az özvegy királynénak halála pillanatában tizennyolc ${ }^{53}$, több darabból álló öltözete ${ }^{54}$ volt, ráadásul több köpenye, kabátja és egyéb kiegészítő ruhadarabja, melyek elnevezéseinek fordítása és azonosítása meglehetősen bonyolult.

A különféle öltözékeknél az inventárium említi a színüket, az anyagukat, hogy hány darabból állnak és hogy szőrmével szegélyezettek-e. Ez utóbbi azért volt lényeges, mert az úgynevezett menu vai ${ }^{55}$ használata csak az arisztokrácia számára volt megengedett. ${ }^{56}$

Legdrágább ruhája egy öt darabból álló öltözet lila bársonyból, amihez egy pöttyös szőrmével szegélyezett palást is tartozott. Ezt 180 livre-ért vásárolta meg Madame de Beaumarchès, jóllehet értékét csak 120 livre-re becsülték. ${ }^{57} \mathrm{~A}$ királyné valószínúleg különleges udvari alkalmakra tartogatta. A második legdrágább ruha 4 részes volt, szintén bársonyból készült, 70 livre-re becsülték és 80 livre-ért kelt el. ${ }^{58}$ Majdnem ennyibe került az a díszes köpeny is, amiben a királyné házasságra lépett, 70 livre-ért vásárolták meg. ${ }^{59} \mathrm{Nem}$ tudhatjuk, hogy a királyné nagy értéke miatt, vagy érzelmi okokból őrizte meg ezt a ruhát, hiszen az esküvő 1315. augusztus 19én volt, vagyis 13 éve volt a királyné ruhatárában.

A többi öltözéke 100 sou ${ }^{60}$ és 36 livre ${ }^{61}$ közötti áron kelt el. A ruhák árát valószínüleg az anyaguk is befolyásolta. Klemencia ruhái drága és különleges szövetekből készültek. Bársonyból (velour) ${ }^{62}$ készült a két legdrágább ruhája, de emellett különféle selymeket is találunk ${ }^{63} \mathrm{~A}$ cendal-nak nevezett tafotához hasonló selyemanyagot gyakran használták a ruhák szegélyezéséhez. ${ }^{64} \mathrm{~A}$ camocas (camoquois) néven említett anyagból három ruhát is varrtak neki. ${ }^{65}$ Ez vagy drága selyemanyag, vagy arany szálakkal átszőtt drága szövet ${ }^{66}$ lehetett. Több ruhája a marbré/meschi nevű anyagból készültt ${ }^{67}$, melyet leginkább Itáliában készítettek: különféle színű szálakat szőttek össze, anélkül, hogy ezeket teljesen összekártolták volna, így az anyag mozgás közben változtatta a színét, és márványos hatást keltett. ${ }^{68} \mathrm{Klemencia} \mathrm{lila}^{69}$, vörös ${ }^{70}$ és barna ${ }^{71}$ szálakból szőtt szövetekből varratott ruhákat magának. Ugyancsak készültek ruhái escarlate anyagból, amely nagyon értékes és jó minőségű szövet volt, leggyakrabban piros színű, de elő tudták állítani kék vagy lila, ritkábban fekete és fehér színekben. ${ }^{72}$ Klemencia ruhatárában egy kék ${ }^{73}$, egy lila ${ }^{74}$ és egy fekete ${ }^{75}$ escarlate ruhát találunk. Három ruhának az alapanyagát pedig teveszőrből szőtték. ${ }^{76}$

51 Proctor-Tiffany 2007. 96.

52 A szabó felesége Klemencia keresztlánya volt, akinek egy márványos lila színủ cote-ot és sercot-ot adott, a sercot-ot menu vair, vagyis pöttyös szörme szegélyezte. Item 274 . „une cote et un sercot de marbré violet, donc le sercot est fourré de menu vair, donné à la fame Johan de Gaangni le tailluer, fillole Madame"

53 Item 267-271., 275-278., 283-289., 293., 299.

54 Robe: általában több (Klemencia inventáriumában 2-5) különféle ruhát magába foglaló öltözet, női ruha. Jobbára egy cote (általában bokáig érő, szűk és hosszú ujjú ruhadarab, amelyet férfiak és nők egyaránt hordtak az ingük felett), sercote (a cote felett hordták, általában szabadban, nyitott, időnként csipkével szegélyezett, köpenyszerủ ruhadarab, széles ujjakkal, ami látni engedi az alatta viselt cote-ot) és mantel (bő, kör alakú külső ruha, vagy köpeny, ami az elülső részén alul nyitott, és/vagy a vállon, vagy elöl záródik) együttese, Proctor-Tiffany 2007. 291-294.

55 Pöttyös szőrme, mellyel gyakran szegélyezték a ruhák külső részét, Proctor-Tiffany 2007. 293.

56 Proctor-Tiffany 2007. 97.

57 Item 276. „une robe de violet veluiau, de 5 garnemens, fourrée de menu vair, présié 120 I par.;vendu à madame de Beaumarchès, 180 I. par"

58 Item 277. „une robe de veluau encendrez, de 4 garnemens, fourrée de menu vair, présié 70 I par.;vendu (...)80 I. par”

59 Item 183. „un bource à pelles broudée, en quoi Madame fut espousée, vendue (...)70 l”

60 Item 299.

61 Item 278.

62 Item 275-277., 283.

63 Item 284-285.

64 Proctor-Tiffany 2007. 292. Az inventárium fekete (Item 278-289.), kék (Item 279., 292-293., 299.) és lila (Item 275.) színű cendal-t említ, egynél pedig nem határozza meg a színt (Item 301.).

65 Item 290-291., 294.

66 Proctor-Tiffany 2007. 292.

67 Item 267-268., 270., 274., 279., 281-282., 301-302.

68 Proctor-Tiffany 2007. 100.

69 Item 274.

70 Item 267-268., 279., 282

71 Item 281., 302.

72 Proctor-Tiffany 2007. 293.

73 Item 269.

74 Item 296.

75 Item 297.

76 Item 289., 292., 298. Ezt a szövetet camelin-nek nevezték, és közepes minőségűnek számított. Proctor-Tiffany 2007. 292. 


\section{A 14. SZÁZADI ANYAGI KULTÚRA TÜKRÖZŐDÉSE MAGYARORSZÁGI KLEMENCIA HALOTTI INVENTÁRIUMÁBAN}

Mint az a fentiekből is látszik, Klemencia ruhatára meglehetősen színes volt. A leggyakoribb színek a sötétvörös ${ }^{77}$ és a lila ${ }^{78}$, melyek meglehetősen drága színek lehettek. Ennek ellenére nagy számban fordulnak elő, így feltételezhető, hogy ezek voltak a királyné kedvelt színei. A vörös szín utalhat az Árpádok vörös-ezüst címerére is.

E két színen kívül kék ${ }^{79}$, fekete ${ }^{80}$, barna ${ }^{81}$ és fehér8 öltözékek szerepelnek még a felsorolásban, bár nem minden esetben adták meg a ruha színét. A francia uralkodóházra jellemző azúrkék szín nem dominál a felsorolt öltözékekben, a fekete valószínüleg a gyász színe. ${ }^{83}$

\section{A királyné szépségápolási tárgyai}

Klemenciát a korszak leírásai különösen szépnek tartották. Személyes tárgyai közül több a szépségápolás és a tisztálkodás céljait szolgálta. Tizenöt különböző mosdótála ${ }^{84}$ volt ezüstből vagy aranyozott ezüstből. Ezek egy részét talán az asztalnál használták, hogy az étkezésnél kezet tudjanak mosni, de néhány kifejezetten arcmosásra szolgált. Több tükre is voltt ${ }^{85}$, köztük egy köpenyeges szarvast ábrázoló, Franciaország és Magyarország címerével. ${ }^{86} \mathrm{Az}$ egyik tükre ezüstből készült és zománcozott volt ${ }^{87}$, a két másik elefántcsontból ${ }^{88}$ készült és az egyikhez fésú is tartozott. ${ }^{89} \mathrm{Nem}$ tudni, hogy ezeket valóban fésülködésre, vagy inkább a haj feltűzésére használták-e. A haj szétválasztásához is volt egy speciális eszköz, Klemenciáé kristályból készült és arannyal díszítették. ${ }^{90} \mathrm{Az}$ arcukat színezték is, ezt bizonyítja, hogy a hagyatékban púderes doboz is volt ezüstből. ${ }^{91} \mathrm{~A}$ hölgyek rózsavízzel illatosították magukat, a hagyatékban több fiolányi rózsavíz szerepel. ${ }^{92}$

\section{A királyné asztala}

Az asztali díszedények számos fajtáját nevezik meg az inventáriumok, ezek pontos azonosítása, és konkrét tárgyakkal való megfeleltetése nehézkes, mert bár nagy számban készültek, csak kevés maradt fenn belőlük, s az elnevezések egyaránt utalhatnak formára, ürmértékre és rendeltetésre. ${ }^{93}$

Klemencia több száz asztali ötvöstárggyal rendelkezett, ezek nagyrészt ezüstből, vagy aranyozott ezüstből készültek. A kevés színarany tárgy külön fejezetet képez az inventáriumban, melyek közül kiemelkedik egy díszes talpú, fedővel rendelkező „,hanap" ${ }^{\prime 94}$, ami önmagában 485 livre-ért kelt el. ${ }^{95}$ Két másik hanap ${ }^{96}$, egy lábas csésze ${ }^{97}$, egy serleg ${ }^{98}$ és egy oroszlán alakú kis sótartó ${ }^{99}$ készültek még aranyból. A királyné személyes használati tárgya lehetett a két arany kanál és egy arany villa ${ }^{100}$, ami Klemencia újdonságok iránti érdeklődését mutatja. Bár a villa már a 11. században megjelent Európában, csak a 13-14. században vált népszerűvé, s ekkor még igazi luxuscikknek számított. A nápolyi hatás ebben az esetben sem kizárható, egy Nápolyi Róbert idejében készült szakácskönyvben a villát a lasagne fogyasztásának kellékeként említik. ${ }^{101}$

77 Item 267-268., 279., 282., 288.

78 Item 274., 276., 285., 290., 294., 296., 300.

79 Item 269., 291.

80 Item 283., 286., 297.

81 Item 281., 302.

82 Item 289.

83 Proctor-Tiffany 2007. 101.

84 Item 138-140., 163., 174., 176.

85 Item 118., 131., 154-156., 420.

86 Item 118. „un cerf enmantelé esmallié de France et de Hongrie, et un mirouer”

87 Item 154. „un mirouer d'argent esmallié"

88 Item 420. "Item, un mirouer et une boueste, d'ivoire, $8 \mathrm{~s}$ "

89 Item 156. „un pigne et mirouer d'yvoire”

90 Item 68. „une gravouere de crystal garnie d'or"

91 Item 131. „un estui d'argent à poudre”

92 Item 122.,135.,157.

93 Kovács 1998. c. 275-276.

94 Talpas, átmérőjéhez viszonyítva magas edényforma, különféle funkciókat láthat el. Kovács 1998. c. 276.

95 Item 188. „un hanap d'or à couvercle, séant sur un trépié d'un serpent, .... vent 485 I par”

96 Item 190., 193.

97 Item 189.

98 Item 192.

99 Item 191. „une petite salière en guise de lyon”

100 Item 195. „deux culliers et une fourchète d'or"

101 Proctor-Tiffany 2007. 88. A villa ritkaságát mutatja, hogy Klemencia franciaországi kortársai közül csak Jeanne de Evreux rendelkezett villával, és 100 évvel később VI. Károlynak is csak három darab volt, Huffelman 1911. 71., 1363-ban V. Károlynak is volt néhány villája, Proctor-Tiffany 2007. 88. 
Az asztalnál az aranyból és ezüstből készült edények egy részét használták csak az étkezésekhez, más tárgyak inkább reprezentációs célokat szolgáltak, ezek a lakomák során egy külön asztalon voltak közszemlére téve. ${ }^{102}$

A lakomák fontos kellékei voltak a só, füszer, asztalkendő és egyebek tárolására szolgáló tartók. Az inventárium összesen 9 sótartót említ ${ }^{103}$, ezek közül kettő szarvas ${ }^{104}$, egy oroszlán alakú ${ }^{105}$, egyet pedig zománcozott kígyók díszítenek. Az inventáriumban szereplő gallie-k és nef-ek egyaránt hajó alakú tárolóedények voltak. Az előbbiből kettőt találunk a felsorolásban, az egyik aranyozott ezüst ${ }^{106}$, a másik nagyméretű aranyozott darab zománcképekkel, melyek négy majmot ábrázolnak. ${ }^{107}$ Ezek a tárgyak igen értékesek voltak: a kisebbiket 107 livre-ért, 9 sou-ért és 4-dénárért, a nagyobbikat 203 livre-ért és 10 sou-ért vásárolta meg a király.

Klemencia birtokában volt még két nef ${ }^{108}$, az egyik zománcozott, aranyozott ezüstből, mely 128 livre-ért és 5 sou-ért talált gazdára ${ }^{109}$, a másik egy ezüst nagyméretű hajó, amely egy kígyónyelvvel volt díszítve. ${ }^{110} \mathrm{~A}$ kígyónyelvet hatékony amulettnek gondolták, és az asztalon tartották, hogy megvédje őket a mérgektől és tisztán tartsa az ételeket. ${ }^{11}{ }^{1} \mathrm{Klemencia}$ inventáriumában több ilyen tárggyal is találkozunk: említ egy korallból készült fát kígyónyelvvel ${ }^{112}$, és 3 zománcozott sótartót kígyókkal. ${ }^{113}$

\section{Lovak és hintók}

Mind a lovak, lószerszámok, mind a hintók státusszimbólumnak számítottak, Szép Fülöp 1294-ben megtiltotta a hintók birtoklását a polgárságnak. Klemenciának több mint hét hintó állt a rendelkezésére. A legértékesebbet, egy textiliákkal bevont hintót, amiben csak ő utazott, kísérete nélkül, 115 livre-ért árverezték el. ${ }^{114}$ Ezt öt ló húzta, melyek díszes szerszámzatát külön tételként 12 livre-ért vásárolták meg. ${ }^{115} \mathrm{Az}$ udvarhölgyei által használt hintó ugyancsak textilbevonatos volt, 36 livre-ért kelt el. ${ }^{116}$

Klemenciának 24 lova volt ${ }^{117}$, ezek közül a legdrágább a királynéi fogatot húzta, és feltehetően a többi lovat irányította, önmagában 120 livre-ért adták el. ${ }^{118}$

Klemenciának több nyerge is volt, a legdíszesebbet lila bársonnyal borították és ezüst veretekkel ékesítették, és Magyarország és Puglia címerével díszítették. ${ }^{119}$ Talán Nápolyból hozta magával, vagy esetleg dél-itáliai rokonaitól kapta ajándékba.

Jelen tanulmányom leginkább ízelítóként szolgálhat arra vonatkozóan, hogy egy királyné környezetében, kápolnájában, illetve viseleti és használati tárgyai között milyen tárgytípusok fordultak elő. Igyekeztem a magyar vonatkozású elemeket kiemelni, és szándékosan nem foglalkoztam a királyné kápolnájával és kegytárgyaival, valamint a könyvkultúrával, amely külön tanulmány témája lehetne, hiszen Klemencia könyvtára sok kötetet tartalmazott, közülük máig fennmaradt a Peterborough-i Zsoltároskönyv és Ovidius Moralisè-jének egy kódexe. Fő célom az volt, hogy felhívjam a figyelmet erre az érdekes forrásra, amelyet különösen fontossá tehet számunkra, hogy a magyar Anjou-korból nincsenek hasonló részletességű hagyatéki forrásaink, így kiváló analógiául szolgálhat a királyi és királynéi reprezentáció, a művelődéstörténet és a művészettörténet kutatói számára.

102 Proctor-Tiffany 2007. 87-88. Ez kitűnik Jean de Limbourg Január-miniatúráján is a Très Riches Heures című kódexben, mely Jean de Berry herceg lakomáját ábrázolja. A miniatúra bal oldalán láthatóak egy külön kis asztalon a különféle díszedények. A hercegi asztalon pedig számos étkezési célú edény mellett egy medvével és hattyúval díszített nef (díszhajó) foglal helyet, amiröl a későbbiekben még szót ejtek. Kovács 1998. c. 277., 262-263. kép

103 Item 121., 123., 125., 128., 153., 191.

104 Item 128.

105 Item 191.

106 Item 103. „une galie d'argent dorée à esmaus, (...)valent 107 I 9s 4 d ob., vendu au de Roy et livré comme dessus”

107 Item 104. „une autre grant gallie dorée, emailliée dehors sur 4 babouins, (...)valent 203 I 10s par., vendu au de Roy et livré comme dessus"

108 A tárgytípus későbbi párhuzamairól lásd: Kovács 1998. c. 277-279.

109 Item 143. „un nef d'argent dorée esamilliée, (...), valent 128 I 5 s par”

110 Item 170. „une nef d'argent et une langue de serpent aveques”

111 Proctor-Tiffany 2007. 62.

112 Item 177. „un arbre de courail à langues de serpent”

113 Item 125.

114 Item 504. „le char aus damoiseles, donc la couverture est de drap et de toile, deux selles, une avalouère, et une dossière. Item, une letière sanz hernois et sanz courtine; vend. ensemble 36 I par., à la dame de Beaumarchès"

115 Item 503. „les coliers et les trais de cinq chevaux dudit char, trios selles, l'avalouère, et un dossière, vend. à Guillaume du Moustier, 12 I. par"

116 Item 504. „le char aus damoiseles, donc la couverture est de drap et de toile, deux selles, une avalouère, et une dossière. Item, une letière sanz hernois et sanz courtine; vend. ensemble 36 I par., à la dame de Beaumarchès"

117 Item 483-501. és 677.

118 Item 483. „premièrement, 1 grant cheval morel, qui n'a que 1 oel; et fu du char Madame; vendu à Johan de Bouchon, 120 l”

119 Item 467. „une sambue, à tout le lorain, garnie d'argent, donc la sambue est de veluau violet, et sont les escuex d'argent esmallié de Puille et de Hongrie" 


\title{
A 14. SZÁZADI ANYAGI KULTÚRA TÜKRÖZŐDÉSE MAGYARORSZÁGI \\ KLEMENCIA HALOTTI INVENTÁRIUMÁBAN
}

\section{Összefoglaló}

Klemencia (1293-1328), Károly Róbert húga, bár ténylegesen sosem járt hazánkban, mégis haláláig használta a "Magyarországi" jelzőt. 1315-ben Franciaországba ment férjhez, egy évig volt az ország királynéja, pár napig anyakirálynéja.

1328. október 12-én halt meg, október 18-án hagyatéki leltár készült, amely leírja a királyné tárgyait, azok súlyát és anyagát, közli azok értékét és a későbbi tulajdonosuk nevét. Ez alapján betekintést nyerhetünk az özvegy királyné mindennapi életébe. Használati tárgyai, ruhái, ékszerei és vallási kegytárgyai - bár maguk a tárgyak nem maradtak ránk - a korszak anyagi kultúrája mellett a francia udvari reprezentációról is vallanak.

\section{The inventory of queen Clémence of Hungary as a source of 14th century material culture}

\author{
ANNAMÁRIA BARTHA
}

This article studies the inventory of belongings of Clemence of Hungary (1293-1928), queen of France. The inventory, compiled after Clemence's death, lists 748 „items" as her property and the exact prices for which they were sold. It consists of various pieces of clothing, jewellery, religious and secular works of art, numerous horses and chariots; moreover, the description of the royal tablecloth is recorded by this interesting source of 14 th century cultural history.

\section{Irodalom}

Bartha A. 2013.: Magyarországi Klemencia kapcsolatai Magyarországgal. In.: Francia-magyar kapcsolatok a középkorban. Szerk.: Györkös A. - Kiss G. - Sághy M., Debrecen (megjelenés alatt)

Bertényi I. 2000.: A tizennegyedik század története. Budapest

Brown, E. A. R. 1978.: The Ceremonial of Royal Succession in Capetian France: The Double Funeral of Louis X. Traditio. Studies of Ancient and Medieval History, Thought, and Religion 34. 227-279.

Brown, E. A. R. 1988.: The Chapels and Cult of Saint Louis at Saint-Denis. Medievalia: A Journal of Medieval Studies 10. 279331.

Douët-d'Arcq L. 1874.: Inventarie et vente après décès des biens de la reine Clémence de Hongrie, veuve de Louis le Hutin, 1328. In.: Douët-d'Arcq L.: Nouveau recueil de comptes de l'argenterie des rois de France. Paris, 37-112.

Dümmerth D. 1982.: „Magyarországi Klemencia” Franciaország királynéja. In.: Dümmerth Dezső: Az Anjou-ház nyomában. Budapest, 284-290.

Freeman, M. B. 1963.: A Shrine for a Queen. The Metropolitan Museum of Art Bulletin 21/10. 327-339.

Holladay, J. A. 2006.: Fourteenth-century French queens as collectors and readers of books: Jeanne d'Evreux and her contemporaries. Journal of Medieval History 32. 69-100.

Huffelman, A. M.1911.: Clemenza von Ungarn, Königin von Frankreich. Berlin

Kovács É. 1998. a.: Későközépkori francia inventáriumok magyar vonatkozásai. In.: Kovács Éva: Species modus ordo. Válogatott tanulmányok. A szöveget gondozta Verő Mária és Takács Imre, Budapest, 182-189.

Kovács É. 1998. b.: Két 13. századi ékszerfajta Magyarországon. In.: Kovács Éva: Species modus ordo. Válogatott tanulmányok. A szöveget gondozta Verő Mária és Takács Imre, Budapest, 213-235.

Kovács É. 1998. c.: Világi ötvösművek a középkori Franciaországban. In.: Kovács Éva: Species modus ordo. Válogatott tanulmányok. A szöveget gondozta Verő Mária és Takács Imre, Budapest, 275-281.

Kristó Gy. 2005.: Károly Róbert családja. Aetas 35/4. 14-28.

Lalou, E. 1991.: Klementia v. Ungarn. In.: Lexikon des Mittelalters Vol. 5. München-Zürick, 1205-1206.

Proctor-Tiffany, M. 2007.: Portrait of a medieval Patron: The inventory and gift giving of Clémence of Hungary. Providence, Rhode Island

Sroka, S. A. 1998.: Klemencia. In.: Sroka, Stanislaw A.: A magyar Anjouk családi története. Kraków, 24-25. 
